\title{
The effects of soy isoflavones on obesity
}

Ørgaard, Anne; Jensen, Lotte

Published in:

Experimental Biology and Medicine (Maywood)

DOI:

10.3181/0712-MR-347

Publication date:

2008

Document version

Early version, also known as pre-print

Citation for published version (APA):

Ørgaard, A., \& Jensen, L. (2008). The effects of soy isoflavones on obesity. Experimental Biology and Medicine (Maywood), 233(9), 1066-80. https://doi.org/10.3181/0712-MR-347 


\section{Experimental Biology and Medicine \\ http://ebm.sagepub.com/}

\section{The Effects of Soy Isoflavones on Obesity \\ Anne Ørgaard and Lotte Jensen \\ Exp Biol Med (Maywood) 2008 233: 1066 \\ DOI: 10.3181/0712-MR-347}

The online version of this article can be found at:

http://ebm.sagepub.com/content/233/9/1066

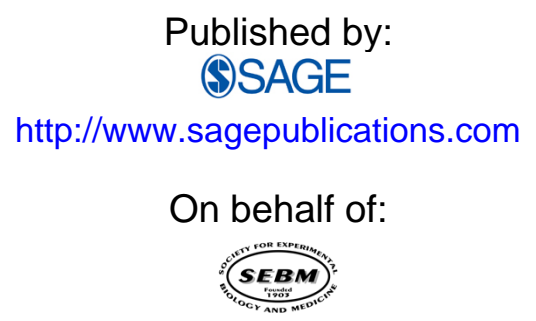

Society for Experimental Biology and Medicine

Additional services and information for Experimental Biology and Medicine can be found at:

Email Alerts: http://ebm.sagepub.com/cgi/alerts

Subscriptions: http://ebm.sagepub.com/subscriptions

Reprints: http://www.sagepub.com/journalsReprints.nav

Permissions: http://www.sagepub.com/journalsPermissions.nav

>> Version of Record - Sep 1, 2008

What is This? 


\title{
MINIREVIEW
}

\section{The Effects of Soy Isoflavones on Obesity}

\author{
Anne Ørgahid and Lotte Jensen ${ }^{1}$ \\ Department of Veterinary Pathobiology, Faculty of Life Sciences, University of Copenhagen, \\ Copenhagen, Denmark
}

\begin{abstract}
Over the last decades, the prevalence of obesity and related diseases has increased rapidly in the Western world. Obesity is a disorder of energy balance and is associated with hyperinsulinemia, insulin resistance, and abnormalities in lipid metabolism, and it is one of the most important risk factors in the development of Type II diabetes, cardiovascular disease, atherosclerosis, and certain cancers. Because of the lower frequency of these diseases in Asian countries, attention has been turned toward the Asian diet, which consists highly of soy and soy-based products. The health benefits associated with soy consumption have been linked to the content of isoflavones, the main class of the phytoestrogens. As a result of their structural similarities to endogenous estrogens, isoflavones elicit weak estrogenic effects by competing with 17ß-estradiol (E2) for binding to the intranuclear estrogen receptors (ERs) and exert estrogenic or antiestrogenic effects in various tissues. The estrogenic activities of soy isoflavones are thought to play an important role in their health-enhancing properties. Additionally, the isoflavones have been proved to exert non-ER-mediated effects through numerous other pathways. Genistein, daidzein, and glycitein are the principal isoflavones in soy. Genistein is the most thoroughly examined of these, because it is the most prevalent isoflavone in soy and the most active of these compounds, because of its higher binding affinity for the ER. Genistein and daidzein can be obtained in high levels in humans under certain nutritional conditions, and epidemiologic and laboratory data suggest that these compounds could have health benefits in human obesity. This review will focus on the
\end{abstract}

Funding support was provided by the research project BEST ("build a healthy life").

${ }^{1}$ To whom correspondence should be addressed at Department of Veterinary Pathobiology, Faculty of Life Sciences, University of Copenhagen, Copenhagen, Denmark. E-mail: lottejen@gmail.com

Received December 21, 2007.

Accepted April 26, 2008.

DOI: $10.3181 / 0712-\mathrm{MR}-347$

$1535-3702 / 08 / 2339-1066 \$ 15.00$

Copyright (C) 2008 by the Society for Experimental Biology and Medicine latest results of research on isoflavones and their effect on obesity in cell cultures, rodents, and humans. Exp Biol Med 233:1066-1080, 2008

Key words: obesity; isoflavones; metabolic syndrome

\section{Introduction}

Metabolic Syndrome. Metabolic syndrome is a combination of medical disorders that increase the risk for cardiovascular disease and Type II diabetes. Obesity may lead to metabolic syndrome because it increases the prevalence of visceral obesity, insulin resistance, increased very low-density lipoprotein (VLDL) and low-density lipoprotein (LDL) cholesterol, decreased high-density lipoprotein (HDL) cholesterol, elevated triglycerides, hypertension (high blood pressure), and fatty liver, which are important factors of metabolic syndrome.

Visceral obesity, a hallmark for the male obese phenotype, which is characterized by excess fat storage in and around the abdomen, is the prime cause of metabolic abnormalities; therefore, men are usually at higher risk of cardiovascular disease than women (1). After menopause, the risk for women becomes similar to that for men because estrogen deficiency leads to visceral obesity, which is accompanied by a fall in insulin sensitivity (2).

Tumor necrosis factor- $\alpha(\mathrm{TNF}-\alpha)$ is a cytokine secreted from tissues upon infection as part of the inflammatory response (3). Adipose tissue, especially visceral fat, secretes elevated levels of TNF- $\alpha$, because excess fat storage in adipose tissue causes a state of chronic inflammation (1). TNF- $\alpha$ decreases the responsiveness to insulin, leading to insulin resistance (4). In adipose tissue, insulin stimulates glucose uptake and fatty acid synthesis via activation of sterol regulatory element binding proteins (SREBPs; Ref. $5)$. Insulin resistance is the condition in which normal amounts of insulin are inadequate for producing a normal 
insulin response in fat, muscle, and liver cells, and the condition is characterized by hyperglycemia and hyperlipidemia. Insulin resistance in fat cells results in hydrolysis of stored triglycerides, a process that elevates the concentration of free fatty acids in blood plasma. Elevated blood lipid levels are closely associated with elevated levels of VLDL and LDL cholesterol and decreased levels of HDL cholesterol. Cholesterol synthesis in the liver is particularly stimulated by ingestion of saturated fatty acids and transfatty acids, whereas ingestion of monounsaturated fatty acids and polyunsaturated fatty acids (PUFAs) plays a beneficial role in health by lowering blood levels of triglycerides and VLDL and LDL cholesterol, thereby preventing insulin resistance (6). The main treatment for obesity and related diseases is lifestyle changes, including caloric restriction and exercise. However, drug treatment may occasionally be necessary, and this is where the soy isoflavones are of particular interest.

Soy Isoflavones. The metabolism of isoflavones in animals and humans is complex and is a combination of mammalian and gut microbial processes. In soy products, isoflavones occur to a variable extent as glucosides (genistein, daidzein, and glycitein). After ingestion, isoflavones are hydrolyzed by intestinal glucosidases, which release the aglycones genistein, daidzein, and glycitein (Fig. 1). Genistein and daidzein present in plasma may also be derived from their precursors biochanin A and formononetin (Fig. 1), respectively, after their breakdown by intestinal glucosidases $(7,8)$.

Glucosidase activity results in the production of other metabolites, of which only the daidzein metabolite, equol (Fig. 1), is of relevance in this text. In the following, the term isoflavone will refer to a combination of two or more isoflavone compounds, especially in descriptions of studies in which researchers did not specify which compounds they used.

\section{Regulation of Adipogenesis}

17 $\beta$-Estradiol and Isoflavones. Adipocytes play a central role in lipid homeostasis and the maintenance of energy balance in vertebrate organisms. These cells store energy in the form of triglycerides during periods of nutritional abundance and release it as free fatty acids in times of nutritional deprivation. There are two types of fat depots: brown adipose tissue (BAT) and white adipose tissue (WAT); only WAT is important in terms of obesity. Excess fat consumption can stimulate enlargement of existing adipocytes (adipocyte hypertrophy) and induce differentiation of dormant preadipocytes in the adipose tissue into mature adipocytes (adipocyte hyperplasia) to accommodate the demand for extra storage (9). Several transcription factors have been identified as important regulators of the differentiation pattern of gene expression and the lipid content of fat cells. Hormones, including estrogen, growth hormone, thyroid hormone, glucocorti- coids, catecholamines, glucagons, insulin, and insulin-like growth factor are regulators of adipogenesis (10). 17 $\beta$ Estradiol (E2), the most ubiquitous estrogen, is a major regulator of adipocyte development and adipocyte number in females and males (11). Soy isoflavones are nonsteroidal, diphenolic compounds with a structure closely resembling the steroid structure of E2 (Fig. 1). The biological activity of isoflavones in animals and humans is partly ascribed to the structural similarities between the isoflavones and E2. E2 is biosynthesized by the cytochrome P450 enzyme complex called aromatase and acts predominantly via two distinct nuclear ERs, ER $\alpha$ and ER $\beta$, defined as ligand-inducible transcription factors (12). Binding of E2 to ERs inhibits lipogenesis primarily through decreasing activity of lipoprotein lipase (LPL), an enzyme that regulates lipid uptake by adipocytes (13), and the isoflavone genistein has recently been shown to cause decreases in LPL mRNA in adipose tissue with concomitant decreases in lipid filling of adipocytes $(14,15)$. ER $\alpha$ and ER $\beta$ are both expressed in various cell types, including preadipocytes, adipocytes, vascular endothelium, vascular smooth muscle, and macrophages, all of which are found in adipose tissue, but the ratio between $E R \alpha$ and $E R \beta$ is different in the various tissues (16). $E R \alpha$ and $E R \beta$ differ in the C-terminal ligand-binding domain and in the $\mathrm{N}$-terminal transactivation domain and function as dimers (17). Many studies report a tendency of $\mathrm{ER} \alpha$ to form homodimers, whereas $\mathrm{ER} \beta$ prefers to heterodimerize with $\mathrm{ER} \alpha$ (17). ER $\beta$ is known to modulate $\mathrm{ER} \alpha$ transcriptional activity as an activator at low concentrations of E2 and as an inhibitor at high concentrations of E2. E2 has equal binding affinities for ER $\alpha$ and $E R \beta$ (18), whereas the isoflavones genistein and daidzein have greater binding affinity for $\operatorname{ER} \beta$ than for $\operatorname{ER} \alpha(17,18)$. $\operatorname{ER} \beta$ is found in 5 different splice variants: ER $\beta 1$ through ER $\beta 5$. Not much is known about the roles of these isoforms, which may function differently (19), but genistein has been shown to preferentially bind to ER $\beta 1$. The differences between the ER subtypes in relative ligand binding affinity and tissue distribution may contribute to the selective action of ER agonists and antagonists in different tissues.

Adipogenic Transcription Factors and Isoflavones. Adipogenesis is regulated by the hormonally induced cooperative interaction between members of the CCAAT/enhancer binding protein $(\mathrm{C} / \mathrm{EBP})$ and peroxisome proliferator-activated receptor (PPAR) families, the primary adipogenic transcription factors. They act by synergistically transactivating the expression of several adipogenic effector genes (16). Furthermore, SREBPs enhance adipocyte development and regulate intracellular sterol and lipid homeostasis (20). There are three main isoforms of SREBPs. SREBP-1a and SREBP-1c are two splice variants of the same gene product, and they are primarily responsible for the regulation of genes involved in fatty acid synthesis and metabolism. SREBP-2 is encoded by its own gene and is primarily responsible for the regulation of genes involved in cholesterol synthesis and metabolism (20). 
<smiles>CC12CCC3c4ccc(O)cc4CCC3C1CCC2O</smiles><smiles>COc1ccc(-c2coc3cc(O)cc(O)c3c2=O)cc1</smiles><smiles>COc1ccc(-c2coc3cc(O)ccc3c2=O)cc1</smiles><smiles>COc1cc2c(=O)c(-c3ccc(O)cc3)coc2cc1O</smiles><smiles>Oc1ccc(C2=COc3cc(O)ccc3C2)cc1</smiles>

Figure 1. Chemical structures of $17 \beta$-estradiol (estradiol) and the soy isoflavones.

PPARs exist in three subclasses: PPAR $\alpha$, PPAR $\beta / \delta$, and PPAR $\gamma$. PPAR $\alpha$ is important for $\beta$-oxidation of fatty acids and is mainly expressed in tissues such as the liver, kidney, heart, and muscle, where lipoprotein metabolism is important. Little is known about PPAR $\beta / \delta$, but it has been shown that PPAR $\beta / \delta$ activation stimulates fatty acid oxidation and loss of adipose mass in genetically obese mice (21). PPAR $\gamma$ is mainly expressed in adipose tissue and is considered the master regulator of adipogenesis. It is also involved in lipid storage and glucose and cholesterol metabolism (16).

Three different isoforms of PPAR $\gamma$ are known: PPAR $\gamma 1$, which is the form expressed in virtually all tissues; PPAR $\gamma 2$, which is specific to adipose tissue; and PPAR $\gamma 3$, which is expressed in macrophages, large intestine, and WAT. The adipogenic transcription factors induce the expression of adipocyte-specific genes, ultimately leading to a morphologically distinct and functional fat cell. The expression of PPAR $\gamma 2$ and LPL is considered to be an early marker of adipocytes (22).

Increasing evidence has established that isoflavones not only act through ERs but also exert effects through numerous other pathways, such as those regulated by PPARs. Unlike the highly specific ERs, PPARs bind a wide number of ligands and directly affect lipid metabolism by 
Activation of PPAR $\alpha$
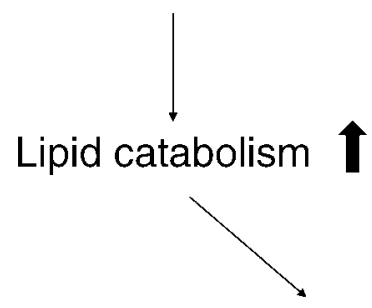

Lipids in blood $\downarrow$

Figure 2. Pathways in lipid metabolism regulated by PPARs.

enhancing transcription of PPAR-regulated genes. Upon ligand binding, PPAR heterodimerizes with retinoid $\mathrm{X}$ receptor (RXR) and binds to peroxisome proliferator response element (PPRE) sequences located within the promoters of PPAR-regulated genes $(23,24)$. Ligands for PPAR $\gamma$ include prostaglandins and some unsaturated fatty acids and their derivatives, whereas ligands for PPAR $\alpha$ include some saturated and unsaturated fatty acids as well as fenofibrates, hypolipidemic agents used to manage elevated blood lipid levels and Type II diabetes $(23,25)$. Especially PUFAs activate PPAR $\alpha$ (26), which explains why high dietary intake of PUFAs positively influences lipid homeostasis. Generally, PPAR $\alpha$ controls the transcription of many genes involved in lipid catabolism, whereas PPAR $\gamma$ controls the expression of genes involved in adipocyte differentiation and insulin sensation. Together, activation of PPAR $\alpha$ and PPAR $\gamma$ increases $\beta$-oxidation and insulin sensation, whereas blood and liver lipid concentrations are typically reduced (Fig. 2). It has recently been shown, that genistein and daidzein, but not glycitein, can bind directly to and activate both PPAR $\alpha$ (27) and PPAR $\gamma(28,29)$, and a study by Harmon et al. (30) showed that genistein can also downregulate the expression of PPAR $\gamma$ and C/EBP $\alpha$ in 3T3-L1 cells by inhibiting $\mathrm{C} / \mathrm{EBP} \beta$ activity. Genistein can act as a tyrosine kinase inhibitor and thereby block the tyrosine phosphorylation of $\mathrm{C} / \mathrm{EBP} \beta$, which is necessary during adipogenic differentiation. However, it should be noted that this may not be of any physiologic relevance, as the experiment was carried out with genistein levels much higher than those that can be achieved in vivo under normal nutritional conditions. In this study, it was not possible to detect any tyrosine kinase inhibitory action or adverse effect of daidzein on adipogenesis, but other experiments have indicated a role for daidzein as well as for genistein in the regulation of adipogenesis (31). Because adipogenesis is regulated by an abundance of mechanisms on many levels, extensive work is being conducted to evaluate the potentially beneficial effects of isoflavones on obesity (in vivo) and to sort out the pathways responsible for these effects (in vitro).

\section{Isoflavone Effects In Vitro}

Because many mechanisms are involved in adipogenesis, distinct cell lines are needed to investigate different steps of the process. As adipocytes and osteoblasts arise from the same bone marrow mesenchymal precursor cells (22), different strains of osteoprogenitor cells from bone marrow are commonly used to investigate the regulation of differentiation to adipocytes. The mechanisms of preadipocyte replication and differentiation are frequently investigated by using the murine cell line 3T3-L1. Mature 3T3L1 cells and rat adipocytes are used as models of mature adipocytes. Furthermore, the human hepatoma cell line HepG2, which does not express ER, is an important tool to evaluate the effects of isoflavones on liver, as this is a central regulation site of metabolism.

The Role of Isoflavones in Adipogenesis and Osteogenesis. When reading the following results form in vitro experiments, the reader should keep in mind that the total genistein concentrations in plasma of humans consuming foods rich in isoflavones range 1 from $1.6 \mu M(32$, 33). Total plasma isoflavone concentration may reach as much as $10 \mu M$ after ingestion of purified isoflavones (34, 35 ), but in vitro experiments in which concentrations of 10 $\mu M$ or higher are used may not reflect any points that are of physiologic relevance in vivo.

Experiments involving mouse bone marrow cells and KS483 osteoprogenitor cells cloned from mouse calvaria have demonstrated that E2 through the ER regulates two key genes for osteogenic and adipogenic commitment: the gene encoding the core-binding factor $\alpha-1(\mathrm{Cbf} \alpha-1)$ and the gene encoding PPAR $\gamma 2$, respectively (12). Interestingly, in human bone marrow cells, genistein has also been demonstrated to be a regulator of these linage-determining genes (15). The E2 stimulation of osteogenesis and concurrent inhibition of adipogenesis may explain the fact that estrogen deficiency decreases bone mass and increases adipose tissue, as seen in postmenopausal women. The mouse bone marrow cells and KS483 cells have also been used to evaluate the effects of genistein on osteogenesis and adipogenesis (28). The results showed that 0.1 to $10 \mu M$ genistein stimulated osteogenesis with a maximum effect at $1 \mu M$, whereas concentrations of 25 to $50 \mu M$ inhibited osteogenesis. At the same time 0.1 to $1 \mu M$ genistein inhibited adipogenesis, whereas concentrations of 10 to 50 $\mu M$ increasingly stimulated adipogenesis. Although it may not be physiologically relevant, this finding indicated that, at a concentration of approximately $10 \mu \mathrm{M}$, the effect of genistein switches from estrogenic to antiestrogenic, and a PPAR $\gamma$ binding assay suggested that the antiestrogenic effect of genistein is due to a direct activation of PPAR $\gamma 2$, leading to the downregulation of ER-mediated transcriptional activity and osteogenesis. This is consistent with other results that showed that genistein is a ligand for PPAR $\gamma$ (36) and that activation of PPAR $\gamma$ downregulates osteogenesis and upregulates adipogenesis (37), but further investigations have also revealed that a direct interaction of genistein with PPAR $\alpha$ plays an important role in adipogenesis $(27,36)$. In agreement with these findings, daidzein, like genistein, has been shown to have biphasic effects on osteogenesis and 

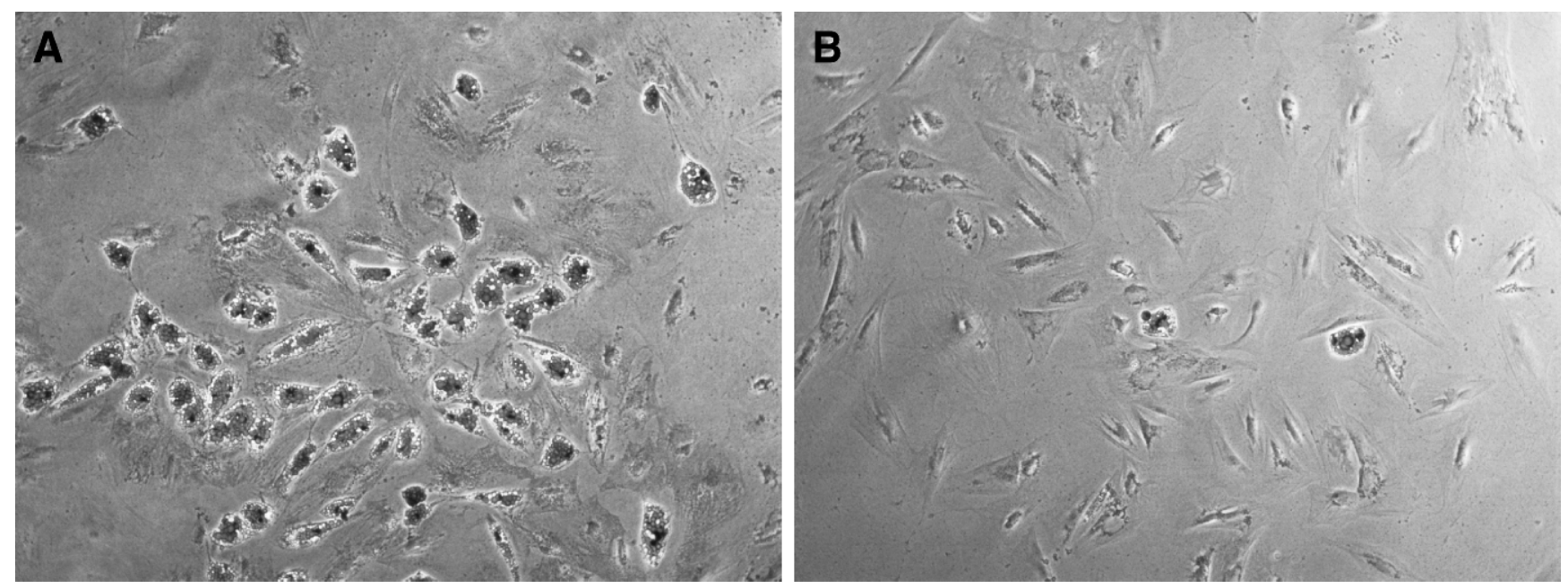

Figure 3. Genistein inhibits differentiation of human preadipocytes. Oil Red O staining (triglyceride staining) of human preadipocytes isolated from subcutaneous abdominal adipose tissue after 15 days with differentiation medium (Dulbecco's modified Eagle's medium/F12, fetal calf serum, insulin, dexamethasone, triiodothyronine, isobutylmethylxanthine). (A) Cells after incubation with $0.1 \%$ dimethylsulfoxide (control). (B) Cells after incubation with $100 \mu M$ genistein and $0.1 \%$ dimethylsulfoxide.

adipogenesis (31). At concentrations below $20 \mu M$, daidzein stimulated osteogenesis and decreased adipogenesis, and at concentrations higher than $30 \mu M$, daidzein inhibited osteogenesis and stimulated adipogenesis. Furthermore, daidzein activated ERs as well as PPAR $\alpha, \operatorname{PPAR} \beta / \delta$, and PPAR $\gamma$ (38). However, it has not been possible to detect any ligand activity of glycitein for PPAR $\alpha$ and PPAR $\gamma$ (36). Taken together, the results of these experiments revealed that the diverse effects of genistein in different tissues cannot solely be explained by the high affinity for ER $\beta$, because ER $\beta$ can act as a dominant negative regulator of estrogenic activity. Instead, the results of these experiments suggest that a complex balance between activated ERs and PPARs is an important mechanism in determining the biological effects of genistein and daidzein. This assumption is highly plausible because the crosstalk between ERs and PPARs has been seen in other cell types (39). The fact that daidzein appears to switch from estrogenic to antiestrogenic action at a higher concentration than genistein may be explained by its lower affinity for the ERs (40).

Isoflavone Effects on Preadipocytes and Mature Adipocytes. In addition to the ability of isoflavones to interact with ERs and PPARs, genistein in high concentrations is a potent inhibitor of protein tyrosine kinase, DNA topoisomerases I and II, and ribosomal S6 kinase. Studies of 3T3-L1 cells have strongly suggested that genistein concentrations of $50 \mu M$ and higher inhibit proliferation of preconfluent and postconfluent preadipocytes and mediate the inhibition of adipocyte differentiation by mechanisms that involve the decreased expression of PPAR $\gamma$ and the activation of the intracellular AMPactivated kinase (AMPK) signaling cascades (41).

In agreement with these findings, we have observed a decrease in adipocyte differentiation of primary human preadipocytes with a genistein concentration of $100 \mu M$
(Fig. 3; unpublished results). One experiment demonstrated that genistein concentrations of 10,100 , and $1000 \mu M$ significantly restricted lipogenesis and contemporarily induced lipolysis at the 100 and $1000 \mu M$ concentrations, whereas E2 at the same concentrations did not have any significant effects (42). These results confirmed that the effects of genistein can be mediated by mechanisms not involving ERs. Furthermore, lipogenesis was inhibited when glucose and acetate were used as substrates. This result suggests not only that genistein not only obstructs glucose uptake by inhibiting glucose transporter 1 (GLUT1) and glucose transporter 4 (GLUT4) (43) but also that this phytoestrogen is capable of inhibiting pathways of lipogenesis after acetyl-CoA formation (42).

Isoflavones and Apoptosis. Several recent studies have suggested that induction of apoptosis may contribute to the reducing effect of isoflavones on adipose tissue. As little as $10 \mu M$ genistein significantly increases apoptosis of mature adipocytes after $24 \mathrm{hrs}$ but not of preadipocytes (44). Hwang et al. (41) showed that the ability of genistein to activate the AMPK signaling cascades in mature 3T3-L1 adipocytes was involved in the promotion of adipocyte apoptosis. Recent results have demonstrated that genistein also induces apoptosis of HepG2 cells (45). As HepG2 cells do not express ERs, this result is consistent with those in other reports that genistein has multiple effects and induces apoptosis by mechanisms that do not involve ERs (46).

Isoflavone Effects on Hepatocytes. In various populations consuming foods rich in isoflavones, total genistein concentrations in plasma have been shown to be between 1 and $4.6 \mu M$, and it is impossible to achieve a serum genistein concentration $>10 \mu M$ through diet. However, isoflavones are subject to extensive first-pass clearance by the liver; therefore, it is possible that hepatocytes in vivo may be exposed to isoflavone concen- 
trations higher than $10 \mu M$. This hypothesis is interesting because a recent study reports that $10 \mu M$ genistein activates PPAR $\alpha$, and subsequently induces expression of PPAR $\alpha$ target genes involved in both mitochondrial and peroxisomal fatty acid $\beta$-oxidation in HepG2 cells (27). These results suggest that genistein treatment increases energy expenditure through enhanced fatty acid catabolism in liver cells, which may contribute to a beneficial effect of isoflavones on hyperlipidemia in obese animals and humans. This is supported by results obtained from studies of obese mice $(47,48)$.

The liver is also the major site of cholesterol synthesis, including synthesis of LDL cholesterol. LDL cholesterol is responsible for carrying cholesterol from liver to tissues and is closely associated with hyperlipidemia and obesity; LDL cholesterol levels correlate with cardiovascular disease. It has been reported that 50 and $100 \mu M$ of both genistein and daidzein, through multiple mechanisms that include inhibition of cholesterol synthesis and esterification, significantly decrease HepG2 secretion of apolipoprotein B, the primary lipoprotein of LDL particles (49). Furthermore, both genistein and daidzein increase LDL-receptor expression and activity, which is in agreement with results from other recent reports (50). The effect of isoflavones on LDLreceptor expression in HepG2 cells has also been demonstrated in a study by Mullen et al. This experiment suggested that isoflavone-containing soy extracts containing $20 \mu M$ genistein and $20 \mu M$ daidzein, respectively, increase the abundance of the mature form of SREBP-2 and the expression of sterol regulatory element (SRE)-regulated genes in HepG2 cells, and these increases in turn result in increases in the surface LDL-receptor expression; thus, plasma cholesterol levels decrease (51). The study detected no significant change in the levels of mature SREBP-1. However, this issue is contradicted by a recent study by Shin et al. (52), who reported that genistein at a concentration of $10 \mu M$ downregulates the abundance of the mature form of SREBP-1 and that this downregulation leads to decreased expression of lipogenic genes, including fatty acid synthetase (FAS), and a subsequent reduction in serum and hepatic triglycerides.

Summary of In Vitro Results. In summary, many mechanisms for isoflavone regulation of adipose tissue in vitro have been suggested, and more will probably emerge. All these findings in cultured cells indicate that isoflavones may have inhibitory effects on adipose tissue enlargement in vivo. However, the isoflavone concentrations used in most in vitro studies far exceed the concentrations that can be obtained in vivo. Furthermore, the exact mechanisms that stimulate apoptosis and preadipocyte mitosis and differentiation in vivo remain elusive. Because of these facts, it is far from certain that all these modes of action of isoflavones will prove to be substantial in vivo.

\section{Isoflavone Effects in Rodents}

Food Intake, Body Weight, and Fat Pad

Weight. Most animal models used to elucidate the effects of isoflavones on obesity are rodent strains with either genetically or diet-induced obesity. Ovariectomy of female animals is also a common tool, as removal of the ovaries causes increases in adipose tissue similar to the increases seen in women after menopause (53). From experiments on animal models, many exciting, but not unambiguous, results of the effect of dietary isoflavones in vivo have been obtained. These in vivo experiments have established that the reducing effects of isoflavones on adipose tissue, as shown in vitro, are not simply reflected in a decrease in body weight in vivo.

It is a matter of debate whether changes in food intake influence the animal results, as this factor is not accounted for in many experiments. It has been reported that isoflavones increase food and water intake (54), whereas others have shown that isoflavones decrease food intake (55, 56). However, all three soy isoflavones-genistein, daidzein, and glycitein-have been demonstrated to affect adipose tissue without affecting food consumption.

For the matter of body weight, it has been reported that dietary genistein at $1000 \mathrm{mg} / \mathrm{kg}$ diet does not affect body weight (57). This was supported by an earlier study that found that body weights in ovariectomized mice were not affected by a diet containing 300 to $1000 \mathrm{mg}$ genistein per kilogram. Similar results have been obtained by other groups from experiments in both mice and rats.

Other experiments in rats have demonstrated that dietary isoflavones significantly decrease body weight and adipose tissue $(56,58)$. This is consistent with a study by Kim et al., which showed that a diet containing $1500 \mathrm{mg}$ genistein per kilogram fed to 9-month-old ovariectomized mice for 3 wks decreased body weight by $9 \%$ and decreased parametrical (PM) fat pad and inguinal (ING) fat pad weights by $22 \%$ and $19 \%$, respectively. A dose of $150 \mathrm{mg}$ genistein per kilogram diet was also examined and showed no effect. Daily food intake was not affected by the dose of $150 \mathrm{mg}$ genistein per kilogram diet, but the dose of $1500 \mathrm{mg}$ genistein per kilogram diet decreased daily food intake by $14 \%$, which may explain at least part of the reduction in body weight (44). The results showed that decreases in individual fat pad weights exceed the decrease in body weight. This suggests that a distinction between fat pad weight and body weight is important when considering whether isoflavones could potentially be used for weight reduction in humans, because these factors do not necessarily correlate.

The ability of genistein to decrease fat pad weight was also demonstrated by Naaz et al., who reported that levels of 500 to $1500 \mathrm{mg}$ genistein per kilogram diet fed to 25- to 27day-old ovariectomized mice for 12 days decreased PM and ING fad pad weights by $37 \%$ to $57 \%$. Although this study had no surveillance of food intake, the great difference in 
the level of weight reduction between the two experiments may be ascribed to a lower responsiveness of older mice to genistein that was due to reduced sensitivity of the ER. The important role of the ER in the effect of genistein was supported when genistein failed to reduce adipose weight in ER $\propto$ knockout ( $\alpha$ ERKO) mice (14). On the basis of results from experiments involving ER $\beta$ knockout ( $\beta E R K O)$ mice, another groups recently suggested that the antilipogenic action of genistein and downregulation of adipogenic genes require the expression of ER $\beta$ (55). These results indicated that interaction and cooperation between $\mathrm{ER} \alpha$ and $\mathrm{ER} \beta$ in the downregulation of estrogen-dependent genes is crucial for the regulation of adipose tissue.

Of the three soy isoflavone components, glycitein has the weakest effect, yet its estrogenic activity in vivo has been reported. Although glycitein accounts for only approximately $10 \%$ of the total isoflavones in soy foods, its biological potency has been shown to be comparable to that of other soy isoflavones (59).

Significant improvements in serum triglyceride levels provided by the intake of soy isoflavones have also been demonstrated in experiments in which PPAR $\alpha$ knockout mice were compared to wild-type mice (60). Improvements in serum triglycerides appeared to occur via both PPAR $\alpha$ dependent and PPAR $\alpha$-independent mechanisms, with the PPAR $\alpha$-independent mechanisms possibly being mediated by SREBP pathways $(48,60)$. Another explanation may be through isoflavone activation of PPAR $\gamma$, because increased adipocyte differentiation and tissue lipid accumulation results in initially decreased serum triglycerides (61). This is consistent with results of other in vivo studies, which indicated that the actions that occur in response to isoflavone intake resembles actions of both PPAR $\alpha$ and $\operatorname{PPAR} \gamma$ agonists: improvement in blood and hepatic triglyceride concentrations and glucose tolerance, respectively (60). The former are typically under the influence of the PPAR $\alpha$, whereas the latter is typically improved by activation of PPAR $\gamma$ (62).

In a cDNA microarray study there was poor overlap between genes whose expression was altered in mice treated with genistein and mice treated with E2 (55). This supports the fact that the physiologic effects of genistein are also produced through the regulation of pathways that differ from those regulated by E2, because E2 cannot interact directly with PPAR transcription factors.

Isoflavone Effects on Adipocyte Size and Apoptosis In Vivo. Reduction of adipose tissue by isoflavones in vivo is caused by adipocyte apoptosis and reduction of individual adipocyte size. Naaz et al. reported that genistein leads to a decrease in adipocyte size in juvenile ovariectomized mice, caused at least in part by decreases in LPL mRNA in adipose tissue. Thus, similar to the effects of estrogen, the effects of genistein on adipose tissue could be due to an inhibition of the lipogenic LPL that regulates adipocyte lipid uptake (14). Consistent with these results, Manzoni et al. recently reported that isoflavones can significantly reduce adipocyte circumference (63).

It was recently reported that a dose of $1500 \mathrm{mg}$ genistein per kilogram diet increases DNA fragmentation in the ING fat pad by $290 \%$ in ovariectomized adult mice (44), a result that confirms that adipose apoptosis contributes to the genistein-mediated reduction of adipose tissue. DNA fragmentation was not detected in the retroperitoneal (RP) and PM fat pads; this absence suggests that apoptosis by genistein may be fat depot-specific. This hypothesis has also been supported by results of studies of human (64) and rat (65) preadipocytes. However, in vivo, apoptotic cells are rapidly removed by macrophages (66), and this rapid removal makes it difficult to correlate the number of present apoptotic cells to the actual amount of tissue loss. Other factors may also influence the results.

Confounding Factors for In Vivo Experiments. Results from different studies are often difficult to compare because of many variables, such as animal strain, food composition, duration time of the experiment, and differences in analytical methods. One important factor may be the age of the experimental animals. In a study by Naaz et al., daily subcutaneous injections of genistein (80 and $200 \mathrm{mg} / \mathrm{kg}$ body wt) into ovariectomized adult mice for 3 wks decreased PM fat pad weights by $23 \%$ and $37 \%$, respectively, whereas daily subcutaneous injections of genistein $(20$ and $80 \mathrm{mg} / \mathrm{kg}$ body wt) into ovariectomized juvenile mice for 4 wks decreased PM fat pad weights by $36 \%$ and $47 \%$, respectively (14). Comparison of the results for adult and juvenile mice, at a daily dose of $80 \mathrm{mg} / \mathrm{kg}$ body wt (23\% and $47 \%$ reduction in PM fat pad weight, respectively), revealed that the effect of genistein is twice as high in the younger mice. Because no differences in food consumption were recorded, this difference suggests that genistein responsiveness is age-related, but the differences could also be caused by the longer period of injections in the younger mice ( 4 wks vs. 3 wks). In fact, the duration times for all in vivo experiments were highly variable, which makes comparison of the distinct results very inaccurate.

Another factor that seems to be very important is the difference between sexes. This is supported by the fact that the pharmacokinetics of genistein have been reported to be faster in males that in females (67). Most available data on the biological effects of isoflavones on adipose tissue and body weight of animals have been obtained from studies of females. As discussed above, most studies of females have detected a decrease in body weight and fat pad weight with genistein administration, but experiments that have included males may be somewhat more interesting. In one of these studies, a fat-reducing effect of dietary genistein was demonstrated at a concentration $\geq 500 \mathrm{mg} / \mathrm{kg}$ diet in ovariectomized mice, whereas effects in males were only detected at doses of $2000 \mathrm{mg} / \mathrm{kg}$ and higher (48). In another experiment, genistein was demonstrated to increase epididymal and renal fat pads and adipocyte size at daily oral doses up to $50 \mathrm{mg} / \mathrm{kg}$ body wt in male mice, whereas this 
effect was not seen in females (55). The results suggested that at levels similar to those present in Western and Eastern diets, in soy milk, or in food supplements containing soy, genistein is adipogenic in young, immature (4-wk-old) male mice. This effect of genistein, which was not observed in female mice (4 wks old), may be relevant to the sex-specific regulation of adipose development, deposition, function, and metabolism during growth and adulthood (68). However, pharmacologic doses inhibited adipose deposition in both sexes.

The intake of soy isoflavones appears to improve serum cholesterol levels in female, but not male, mice, rats, and hamsters $(60,69,70)$. In contrast to these findings, other experiments involving rats have shown that soy isoflavones can significantly reduce adipocyte circumference (63) and lower hepatic lipid concentrations in male rats (56). It has been suggested that both age and sex may be important, at least for intestinal isoflavone metabolism in humans (71).

With the prospect of using isoflavones in weight-loss diets and for the prevention of diseases related to metabolic disorders, the effects of these compounds have to be analyzed in more detail in humans, with respect to potentially important sex-specific differences. However, it is a fact that the adipose ER varies by depot and with different physiologic states. Preadipocytes isolated from different areas have different adipogenic potential, and the metabolic behavior of mature adipocytes differs from depot to depot $(16,72)$. The findings that isoflavones may have distinct influences on metabolism in males and females and that males have a different number and distribution of ERs compared to females emphasizes that isoflavones may exert some of their actions through the ER. With respect to the sex-specific differences, however, it is important to realize the impact of other hormones such as androgens on adipose tissue (72).

Isoflavone Effects on Lipid Metabolism and Plasma Lipid Levels. High-fat diets increase circulating lipids and adipose tissue, but excessive fat accumulation can also occur in the liver. The liver is the primary organ to regulate metabolism and serum composition, and most of the fatty acids and cholesterol from food are processed here before they reach other tissues. A recent study investigated the changes in hepatic transcriptional profiles by using cDNA microarrays and young (3-wk-old) male mice who had high-fat diet (HFD)-induced obesity and were given a $2000 \mathrm{mg}$ genistein per kilogram diet (47). A group fed HFD and genistein gained 55\% less body weight than the HFDfed group, and 80 of 97 altered transcript levels of hepatic genes were completely normalized by the genistein supplementation. The largest numbers of differentially expressed genes in group fed only the HFD and the group fed HFD and genistein were those involved in metabolism. Of 29 metabolism-related genes altered by the HFD, the expression of 21 genes was normalized or reversed by genistein supplementation; this result suggests that the hypolipidemic effect of genistein could be ascribed in part to the upregulation of genes involved in fatty acid catabolism in liver. Others have reported that genistein supplementation can decrease triglyceride, total cholesterol, and LDL cholesterol levels in the serum and liver of mice $(48,73)$. Furthermore, isoflavone supplementation has also been shown to effectively lower the serum cholesterol level in ovariectomized rats (74). Kirk et al. have demonstrated that the ability of the isoflavones genistein and daidzein to lower serum cholesterol levels may be attributed to an increase in LDL receptor activity (75), which is consistent with results from in vitro studies $(50,51)$.

In contrast to these findings of a positive effect of isoflavones on liver metabolism, there may also be adverse effects on this organ. Fenofibrates, drugs used to lower elevated plasma lipid levels in patients with obesity and diabetes, act by binding specifically to PPAR $\alpha$ receptors (60). Fenofibrates have not been reported to damage the liver in humans. However, sustained activation of PPAR $\alpha$ leads to the development of liver tumors in mice and rats (76). Because isoflavones can reduce serum lipid levels both through PPAR $\alpha$-dependent and PPAR $\alpha$-independent pathways, it has been hypothesized that high levels of isoflavones could be an alternative to fenofibrates (58). A daily dose of $500 \mathrm{mg}$ genistein $/ \mathrm{kg}$ body wt would result in a substantial plasma genistein level. However, Michael et al. have recently reported that chronic supplementation of genistein at more than $500 \mathrm{mg}$ genistein/kg body wt per day adversely affects liver structure and function in rats (58).

Isoflavones and Soy Protein in Rodents. Although many rodent experiments have shown that isoflavones alone decrease liver and plasma lipids, others have shown that decreases in lipids in the liver, plasma, or both are observed only when isoflavones are part of soy protein diets (77). It has also been demonstrated that soy protein without isoflavones suppresses serum cholesterol, triglyceride, glucose, and insulin in mice (78). Experiments using HepG2 cells have suggested that the effect of isoflavone-free soy protein is due to induction of LDL receptor activity (79); this suggestion conflicts with the previously discussed report that both the isoflavones genistein and daidzein may be responsible for increased activity of LDL receptors (75). However, it should be noted that Kirk et al. (75) obtained their results in the presence of soy protein, and the results may be an effect of cooperation between soy proteins and isoflavones. This hypothesis was confirmed in studies of male obese Zucker rats; results of these studies have suggested that the hypocholesterolemic mechanism of dietary soy protein is caused by a cooperative interaction between the protein and isoflavone compounds that lower hepatic lipid concentrations (80). On the basis of these observations, it seems likely that the beneficial effect from soy intake may be due to the cooperative action of severalcompounds within soy. With respect to this, some of the results discussed in this minireview have not accounted for the presence of soy protein in the diets used in the experiments; therefore, the results may have been influenced by this protein. The 
mechanism by which soy protein may bring about the effects of isoflavones on lipids is not known, but it may facilitate the transport of isoflavones in blood or their entry into the target organs, such as liver or muscle cells.

Summary of Results of Rodent Experiments. The results obtained from rodent experiments indicate that the results found in vitro also apply in vivo; thus, isoflavones may have beneficial effects on human health. However, because of intrinsic factors, the effects of isoflavones in humans may not be directly inferred from results achieved in rodents.

\section{Isoflavone Effects in Humans}

Metabolism in Humans and Rodents. Rodents, especially mice, metabolize genistein more quickly than humans do (81). Therefore, it is only physiologically relevant to compare the effects of isoflavones between mice and humans on the basis of serum isoflavone concentrations. Unfortunately, many studies have not included analyses of serum isoflavone concentration. There are numerous situations in which human isoflavone intake produces serum genistein levels equaling or exceeding those causing antilipogenic effects in mice. Ingested genistein doses of a 300, 500, 1000, and $1500 \mathrm{mg}$ genistein per kilogram diet have all been demonstrated, at least in some experiments, to lower body weight and serum levels of triglycerides and total cholesterol in mice. Some researchers have reported these doses to produce serum genistein concentrations of $1.02 \mu M, 1.79 \mu M, 2.55 \mu M$, and $3.81 \mu M$ (14), whereas others have reported that a 1000 to $1500 \mathrm{mg}$ genistein per kilogram diet yielded serum concentrations of 0.97 and 1.12 $\mu M$, respectively (82). The discrepancies between the results may be attributed to differences in the metabolism of genistein between different mouse strains. This must also be the case between different strains of rats and especially between mouse and rat strains. A recent report emphasized this, as it found significant interspecies differences in isoflavone metabolism and overall metabolic profile between female rats, pigs, monkeys, and humans (83).

Humans consuming three meals containing soy milk on a daily basis have serum genistein concentrations up to 4.6 $\mu M$ (32), and human infants fed soy-based infant formula have plasma genistein levels between 1.5 and $4.4 \mu M$ (33). Postmenopausal women consuming soy/isoflavone supplements as an alternative to hormone replacement therapy can ingest isoflavone levels that exceed those in people consuming a high-soy diet (34). Administration of singledose purified isoflavones to human females has resulted in serum isoflavone concentrations ranging from $4 \mu M$ in premenopausal women to approximately $10 \mu M$ in postmenopausal women $(34,35)$. This means that serum genistein concentrations that produce decreases in body weight and serum levels of triglycerides and total cholesterol in mice are within the range of concentrations detected in humans under certain nutritional conditions (33). Despite the great genetic resemblance between humans and rodents, there are essential differences between the species. As an example of this, experiments on mice expressing human PPAR $\alpha$ receptors have revealed that there are intrinsic differences in the properties of the human and mouse PPAR $\alpha$ protein (1). These differences may explain the fact that the rodent liver structure and function can be adversely affected by treatment with high doses of fenofibrates and isoflavones (58), whereas these adverse effects have not been observed in humans.

Results of Clinical Experiments. Numerous studies have been conducted to determine which components of soy exert bioactive effects, and the isoflavones have been a particular subject of interest because of their resemblance to endogenous estrogens. In women, menopause occurs when estrogen production in the ovaries ceases. A natural estrogendeficient phenotype results, which makes postmenopausal women an efficient tool to study the effects of estrogen-like substances, such as isoflavones, in humans. However, the physiologic mechanism by which soy may improve blood lipid profiles in humans has been the subject of many studies, and only a minor part of the clinical data is from investigations of isolated isoflavones. In a 4-week study of 12 Japanese postmenopausal women taking capsules that contained isolated isoflavones (61.8 $\mathrm{mg}$ per capsule per day), serum total and LDL cholesterol levels decreased significantly, whereas no changes were seen in HDL cholesterol, VLDL cholesterol, and triglyceride levels (74). In this study, the women were allowed to eat any additional soy products; therefore, the isoflavone intake during the study was in addition to the common dietary intake among Japanese.

An earlier study of 46 postmenopausal women taking isolated isoflavone extracts found a significant increase in HDL cholesterol and a decrease in apolipoprotein B, the primary apolipoprotein in LDL particles (84). Another contemporary experiment identified a positive association between the intake of isolated soy isoflavones and HDL cholesterol concentrations in postmenopausal women (85).

The reports of positive effects of isolated isoflavones in postmenopausal women have been contradicted by several other experiments. Recently, two studies found that daily treatment of postmenopausal women with $50 \mathrm{mg}$ isoflavones (genistein and daidzein) for 2 months had no effect on energy intake and body weight (86) or on plasma concentrations of lipids, glucose, and insulin (87). These results are consistent with those of an earlier study of postmenopausal women, which showed no significant change in plasma lipids despite a higher isoflavone concentration (150 mg isoflavones daily) and a longer duration time (6 months) (88). More comprehensive studies that investigated the effects of isolated isoflavones on serum levels of total cholesterol, LDL cholesterol, HDL cholesterol, triglycerides, and apolipoproteins in postmenopausal women found no change in any of these parameters (89). Together, these results indicate that the isoflavone contents of soy may not be the exclusive factor responsible for the 
observed beneficial effect of soy consumption on lipid metabolism and body weight.

Some evidence suggests that isoflavones are beneficial to human health only when ingested along with the protein part of soybeans, a hypothesis similar to what has been observed in rodents. Some have even reported that consumption of soy protein depleted of isoflavones can significantly decrease serum concentrations of total LDL cholesterol and triacylglycerols in postmenopausal women $(90,91)$; this result suggests that the proteins may be the active ingredient in soybeans. This possibility has been supported results of studies that compared the effects of the consumption of soy protein with either low or high isoflavone concentration $(92,93)$. They revealed that soy protein, independent of isoflavone concentration, significantly reduced LDL cholesterol and increased HDL cholesterol in both men and women (94-96). According to a recent meta-analysis, however, the isoflavone concentration may actually have a dose-dependent effect when ingested with soy protein (97). The meta-analysis, which compared the results of eight different randomized controlled trials, revealed that high isoflavone intake with high soy protein intake leads to significantly greater decreases in serum LDL cholesterol than low isoflavone intake, demonstrating that isoflavones have LDL cholesterol-lowering effects, at least when ingested with soy protein. The findings of this meta-analysis were recently supported by those of a new meta-analysis that compared the results of 11 randomized controlled trials (98). The conclusion from the more recent meta-analysis was that soy isoflavones significantly lowersd serum total and LDL cholesterol but does not change HDL cholesterol. Soy protein with or without isoflavones also significantly improves lipid profiles. These meta-analyses are of great statistical significance, and they support the idea that the isoflavones exert some of their beneficial effects mainly when they are part of an intact soy source. It has been suggested that the lipidemic state of each person is essential, because beneficial effects may only be obtainable in subjects with hyperlipidemia (90). Adding isoflavone-rich soy protein to a low-fat diet for 3 months in hyperlipidemic men and postmenopausal women significantly reduced total and LDL cholesterol concentrations (92). Another recent study of postmenopausal women with borderline-to-moderate LDL cholesterol elevations found that isoflavone-rich soy protein significantly improves blood lipid profiles (99). These results are clearly supported by both the meta-analyses discussed here, as they both found that consumption of soy protein with isoflavones produced larger reductions in serum LDL cholesterol levels in hypercholesterolemic than normocholesterolemic subjects.

Together the results discussed here suggest a beneficial effect of soy isoflavones on obesity in humans, but consistent with the findings in rodents, these results also suggest that this effect may be dependent on whether the isoflavones are consumed in combination with soy protein.
Equol Production and Probiotics. Whereas the overall composition of diet may influence the absorption and metabolism of phytoestrogens, it is well established that, in humans, the gut microflora is a main contributor to the variation in serum isoflavone profiles among persons who have ingested the same amount of isoflavones under identical experimental conditions $(100,101)$. It has been demonstrated that, as a result of particular individual intestinal profiles, approximately $30 \%$ to $40 \%$ of any given population group can convert daidzein to its metabolite equol. Equol is easily absorbed and possesses substantial estrogenic activity due to its affinity for both $E R \alpha$ and $E R \beta$ (102). Special attention has been given to this compound, as it is more estrogenic than daidzein (40).

In a crossover trial, LDL cholesterol concentrations significantly decreased in equol producers for whom dairy products were replaced by soy-based milk or yogurt; no significant changes were seen in those who did not produce equol (103). Thus, significant LDL cholesterol-lowering effects of isoflavones may be limited to persons who can produce equol. This has recently been supported by studies of postmenopausal women who ingested $75 \mathrm{mg}$ isoflavones daily for up to 1 year (100). These studies revealed that the preventive effect on bone loss and fat accumulation in postmenopausal women depends on the person's equolproducing capacity, with a significant advantage for the equol producers. Interestingly, some reports have indicated that the prevalence of equol producers is higher in Asian countries than in Western countries (104), which may be a contributing factor to the lower prevalence of obesity and related diseases in Asian populations.

The question whether the intestinal conversion of daidzein to equol can be enhanced by probiotics is one of great interest. Probiotics are live microbial feed supplements, which beneficially affect the host by improving his or her intestinal microbial balance. Therefore, probiotics may have a major effect on the bioavailability of isoflavones. An experiment using rats indicated that probiotic microorganisms administered with isoflavones accentuated the antilipogenic effect of isoflavones (63), whereas other studies were unable to detect any probiotic enhancement of the effect of isoflavones (105). More importantly, however, no studies of humans have detected any beneficial effects of consuming soy isoflavones along with probiotics $(106,107)$. Probiotic enhancement of isoflavone actions may be a dead end, but there are several other interesting combinations that can be addressed.

Combined Interventions for Improvement of Isoflavone Actions. Fatty acids must be bound to Lcarnitine before they can enter the mitochondria for degradation. L-Carnitine administration reduces lipid concentrations in animals and humans $(108,109)$ and is therefore often sold as a nutritional supplement. Carnitine palmitoyl transferase 1A (CPT1A) is the enzyme responsible for the transport of acyl carnitine from the cytosol into the mitochondrial matrix and is therefore a rate-limiting 
enzyme in $\beta$-oxidation. Interestingly, the combined administration of genistein and L-carnitine acts synergistically in reducing serum lipid and LDL levels in mice (73). The reducing effect on serum lipids may be due to an enhancing effect on CPT1A, a possibility that was supported by an experiment that showed that cotreatment with genistein and L-carnitine additively increased CPT1A activity in HepG2 cells (110). These results indicate that isoflavones could potentially be a very potent antiobesity drug in combination with one or more synergistic agents.

A recent study that may have even greater relevance for the battle against obesity has demonstrated that the combined intervention of a diet containing soy isoflavones and moderate exercise prevented fat deposition and bone loss and restored serum total cholesterol in ovariectomized mice fed a high-cholesterol diet (111). Exercise alone partially inhibited the increase in serum triglycerides, whereas the combined intervention of exercise and isoflavone supplementation restored triglyceride levels to normal and also even increased the level of HDLcholesterol. This combination has shown promising results in human studies (112) and is interesting because a sedentary lifestyle is believed to be an important contributor to various human diseases; this combination suggests that drugs should only be supplements to exercise and a healthy diet.

Summary of Clinical Experiments. It appears that many of the effects of isoflavones observed in rodents also apply in humans. As seen in rodents, human experiments have also suggested that soy protein is an important factor for the observed results. Even though human studies have not detected a decrease in body weight, the isoflavones appear to have a positive influence on plasma lipid profiles. It is possible that weight reductions may be achieved in humans, if they ingest considerably higher doses of isoflavones than can be obtained through diet, but intake of high concentrations of isoflavones may bring about some unwanted effects as well.

\section{Potential Adverse Effects of Soy Isoflavones in Human Nutrition}

When considering isoflavones as a good and natural agent to reduce obesity, it is important to consider the possible side effects that may be associated with an increased intake of these compounds. Because of the promising results showing beneficial effects of soy intake in animals and humans, the Food and Drug Administration in the United States in 1999 approved the health claim that "soy protein can reduce the risk of coronary heart disease by lowering blood cholesterol levels when included in a diet low in saturated fat and cholesterol." However, if an increase in soy consumption is beneficial to particular disease conditions, there is always the possibility that there will be effects other than those that are desirable. Furthermore, the isoflavone concentrations that produce beneficial effects on obesity in rodents appear not to be as efficient in humans. To produce considerable beneficial effects on obesity in humans, isoflavone or soy extracts may have to be ingested as highly concentrated dietary supplements. In this regard, very high concentrations of isoflavones may unfavorably influence a vast amount of developmental and physiologic parameters.

Reproduction. Serum isoflavone concentrations of 0.42 and $0.72 \mu M$ for genistein and glycitein, respectively, considerably increase uterine weight in mice (59). Others have reported that serum genistein levels as low as approximately $1 \mu M$ significantly increase uterine weight in both mice and rats $(14,82)$, reflecting estrogenic effects on this organ. These findings demonstrate that adipose changes only occur at doses above those that produce uterotrophic effects. This is a concern that must be considered in determining whether genistein and soy could be used for weight reduction in humans, as it may affect fertility and offspring.

Injections of 0.5 to $50 \mathrm{mg}$ genistein/ $\mathrm{kg}$ body wt on neonatal days 1 through 5 resulted in adverse effects on female mouse offspring (113). The genistein-treated female offspring had abnormal ovarian development and prolonged estrous cycles with an increasing severity with exposuredose and age. Reduced fertility was observed in mice that, as neonates, were treated with 0.5 to $25 \mathrm{mg}$ genistein $/ \mathrm{kg}$ body wt, and infertility was observed at a dose of $50 \mathrm{mg}$ genistein/kg body wt (113). Other studies of mice and rats have not found any adverse effect of neonatal exposure to genistein on reproduction in either females or males (114), and several investigations of male reproduction in mice and rats have observed no changes in testosterone production, testis and epididymis weight, or sperm production and concentration, regardless of the starting time and concentration of isoflavone exposure $(115,116)$. However, the important issue of reproduction should be more thoroughly investigated in both sexes.

Mouse and human gene expression is controlled by DNA methylation patterns established early in development (117). A recent study has demonstrated that maternal dietary genistein supplementation of mice during gestation protects offspring from obesity by modifying the fetal epigenome and that these changes persist to adulthood. The dietary level of genistein was $250 \mathrm{mg} / \mathrm{kg}$ diet, which exposed the animals to levels comparable with those received by humans consuming high-soy diets (118). However, this also altered the methylation-dependent susceptibility to disease. These findings support the hypothesis that environmental and nutritional effects on the establishment of epigenetic gene regulatory mechanisms in early life, influence adult metabolism and chronic disease susceptibility (119).

Immune Responses. Total plasma levels of isoflavones and genistein in soy-fed infants range from 2.0 to 6.6 and 1.5 to $4.4 \mu M$, respectively, which is 200 -fold greater than plasma levels in infants fed cow's milk formula or human breast milk (120). Infants are normally exposed to 
only negligible amounts of E2. Therefore, the plasma levels of genistein in soy-fed infants are up to 22,000 times greater than E2 levels (33). Despite the fact that the estrogenicity of the most abundant soy isoflavone, genistein, is only 0.001 to 0.0001 that of $\mathrm{E} 2$, these xenobiotic estrogens may well have unintended effects in the infant. Because E2 is an important regulator of thymic development and immune function, Yellayi et al. examined the thymic and immune effects of genistein in mice. In their study, serum genistein levels in mice consuming feed supplemented with 1000 and 1500 genistein/kg diet were 0.97 and $1.12 \mu M$, respectively, and these mice had thymic weights approximately $10 \%$ and $25 \%$ less than those of controls at the end of 12 days of treatment. The serum level of $1.12 \mu M$ that produced a $25 \%$ reduction in thymic weight is approximately $70 \%$ less than the maximal level in soy-fed human infants of $4.4 \mu M$ (33). These results appear very concerning, but interestingly, the effects of genistein on the thymus and the immune system were reversible and returned to normal after cessation of the genistein treatment. Others have suggested that both genistein and daidzein may in fact be immunostimulatory (121), but women fed soy-formula as infants have an almost 90\% increase in the regular use of allergy and asthma drugs as compared with women in the cow's milk control group (122). Together, these ambiguous results indicate that the effect of soy isoflavones on the immune system is an area that should be more closely examined.

Cancer. Isoflavones, especially genistein, have been extensively investigated in relation to cancer. Originally, because of the lower frequency of certain cancers in Eastern countries, isoflavones were thought to exert numerous beneficial actions on cancer, and vast amounts of papers have supported this idea. However, the role of isoflavones in cancer has become controversial, because some evidence has suggested that isoflavones may actually stimulate tumor growth (reviewed in Ref. 123). Because this interesting subject is beyond the scope of this paper, it shall not be discussed further.

\section{Conclusion}

The results of in vitro studies clearly suggest that isoflavones may have inhibitory effects on adipose tissue enlargement in vivo, and the experiments using rodents and humans demonstrate that some of the beneficial effects may actually apply in vivo. However, in vivo, especially in humans, the actions of soy isoflavones appear to depend on a complicated interaction between many factors, such as the presence of soy protein and particular intestinal bacteria.

Although no clinical studies have recorded a reduction in body weight, the isoflavones may help prevent obesityassociated diseases by improving the plasma lipid profile. With respect to this, more research is needed to elucidate the biological mechanisms of soy isoflavones and to address the potential side effects associated with increased intake of these compounds.

We thank Lykke Charlotte Hindsgaul for proofreading.

1. Stienstra R, Duval C, Ller M, Kersten S. PPARs, obesity, and inflammation. PPAR Res 2007:95974, 2007.

2. Small CJ, Bloom SR. The therapeutic potential of gut hormone peptide YY3-36 in the treatment of obesity. Expert Opin Investig Drugs 2005; 14:647-653.

3. Beutler B, Cerami A. Cachectin (tumor necrosis factor): a macrophage hormone governing cellular metabolism and inflammatory response. Endocr Rev 9:57-66, 1988.

4. Dyck DJ, Heigenhauser GJ, Bruce CR. The role of adipokines as regulators of skeletal muscle fatty acid metabolism and insulin sensitivity. Acta Physiol (Oxf) 186:5-16, 2006.

5. Shimano H. Sterol regulatory element-binding proteins (SREBPs): transcriptional regulators of lipid synthetic genes. Prog Lipid Res 40: 439-452, 2001.

6. Clarke SD. Polyunsaturated fatty acid regulation of gene transcription: a mechanism to improve energy balance and insulin resistance. Br J Nutr 83(Suppl 1):S59-S66, 2000.

7. Stintzing FC, Hoffmann M, Carle R. Thermal degradation kinetics of isoflavone aglycones from soy and red clover. Mol Nutr Food Res 50: 373-377, 2006.

8. Stintzing FC, Hoffmann M, Carle R. Thermal degradation kinetics of isoflavone aglycones from soy and red clover. Mol Nutr Food Res 50: 373-377, 2006.

9. Harp JB. New insights into inhibitors of adipogenesis. Curr Opin Lipidol 15:303-307, 2004.

10. Hausman DB, DiGirolamo M, Bartness TJ, Hausman GJ, Martin RJ. The biology of white adipocyte proliferation. Obes Rev 2:239-254, 2001.

11. Anderson LA, Philip GM. The effects of androgens and estrogens on preadipocyte proliferation in human adipose tissue: influence of gender and site. J Clin Endocrinol Metab 86:5045-5051, 2001.

12. Rosen ED, Walkey CJ, Puigserver P, Spiegelman BM. Transcriptional regulation of adipogenesis. Genes Dev 14:1293-1307, 2000.

13. Misso ML, Murata Y, Boon WC, Jones ME, Britt KL, Simpson ER. Cellular and molecular characterization of the adipose phenotype of the aromatase-deficient mouse. Endocrinology 144:1474-1480, 2003.

14. Naaz A, Yellayi S, Zakroczymski MA, Bunick D, Doerge DR, Lubahn DB, Helferich WG, Cooke PS. The soy isoflavone genistein decreases adipose deposition in mice. Endocrinology 144:3315-3320, 2003.

15. Heim M, Frank O, Kampmann G, Sochocky N, Pennimpede T, Fuchs P, Hunziker W, Weber P, Martin I, Bendik I. The phytoestrogen genistein enhances osteogenesis and represses adipogenic differentiation of human primary bone marrow stromal cells. Endocrinology 145:848-859, 2004.

16. Rosen ED. The transcriptional basis of adipocyte development. Prostaglandins Leukot Essent Fatty Acids 73:31-34, 2005.

17. Kuiper GG, Lemmen JG, Carlsson B, Corton JC, Safe SH, van der Saag PT, van der BB, Gustafsson JA. Interaction of estrogenic chemicals and phytoestrogens with estrogen receptor beta. Endocrinology 139:4252-4263, 1998.

18. Zhu BT, Han GZ, Shim JY, Wen Y, Jiang XR. Quantitative structureactivity relationship (QSAR) of various endogenous estrogen metabolites for human estrogen receptor alpha and beta subtypes: insight into the structural determinants favoring a differential subtype binding. Endocrinology 147:4132-4150, 2006.

19. Pettersson K, Grandien K, Kuiper GG, Gustafsson JA. Mouse 
estrogen receptor beta forms estrogen response element-binding heterodimers with estrogen receptor alpha. Mol Endocrinol 11: 1486-1496, 1997.

20. Horton JD, Shimomura I, Brown MS, Hammer RE, Goldstein JL, Shimano H. Activation of cholesterol synthesis in preference to fatty acid synthesis in liver and adipose tissue of transgenic mice overproducing sterol regulatory element-binding protein-2. J Clin Invest 101:2331-2339, 1998.

21. Wang YX, Lee CH, Tiep S, Yu RT, Ham J, Kang H, Evans RM. Peroxisome-proliferator-activated receptor delta activates fat metabolism to prevent obesity. Cell 113:159-170, 2003.

22. Nuttall ME, Gimble JM. Is there a therapeutic opportunity to either prevent or treat osteopenic disorders by inhibiting marrow adipogenesis? Bone 27:177-184, 2000.

23. Neve BP, Fruchart JC, Staels B. Role of the peroxisome proliferatoractivated receptors (PPAR) in atherosclerosis. Biochem Pharmacol 60: 1245-1250, 2000.

24. Qi C, Zhu Y, Reddy JK. Peroxisome proliferator-activated receptors, coactivators, and downstream targets. Cell Biochem Biophys 32:187204, 2000.

25. Gotto AM. Lipid management in diabetic patients: lessons from prevention trials. Am J Med 112(Suppl 8A):19S-26S, 2002.

26. Clarke SD. Nonalcoholic steatosis and steatohepatitis. I. Molecular mechanism for polyunsaturated fatty acid regulation of gene transcription. Am J Physiol Gastrointest Liver Physiol 281:G865-G869, 2001.

27. Kim S, Shin HJ, Kim SY, Kim JH, Lee YS, Kim DH, Lee MO Genistein enhances expression of genes involved in fatty acid catabolism through activation of PPARalpha. Mol Cell Endocrinol 220:51-58, 2004.

28. Dang ZC, Audinot V, Papapoulos SE, Boutin JA, Lowik CW. Peroxisome proliferator-activated receptor gamma (PPARgamma) as a molecular target for the soy phytoestrogen genistein. J Biol Chem 278:962-967, 2003.

29. Shen P, Liu MH, Ng TY, Chan YH, Yong EL. Differential effects of isoflavones, from Astragalus membranaceus and Pueraria thomsonii, on the activation of PPARalpha, PPARgamma, and adipocyte differentiation in vitro. J Nutr 136:899-905, 2006.

30. Harmon AW, Patel YM, Harp JB. Genistein inhibits CCAAT/enhancer-binding protein beta (C/EBPbeta) activity and 3T3-L1 adipogenesis by increasing $\mathrm{C} / \mathrm{EBP}$ homologous protein expression. Biochem J 367:203-208, 2002.

31. Dang Z, Lowik CW. The balance between concurrent activation of ERs and PPARs determines daidzein-induced osteogenesis and adipogenesis. J Bone Miner Res 19:853-861, 2004.

32. Xu X, Harris KS, Wang HJ, Murphy PA, Hendrich S. Bioavailability of soybean isoflavones depends upon gut microflora in women. J Nutr 125:2307-2315, 1995.

33. Setchell KD, Zimmer-Nechemias L, Cai J, Heubi JE. Exposure of infants to phyto-oestrogens from soy-based infant formula. Lancet 350:23-27, 1997.

34. Setchell KD, Brown NM, Desai P, Zimmer-Nechemias L, Wolfe BE, Brashear WT, Kirschner AS, Cassidy A, Heubi JE. Bioavailability of pure isoflavones in healthy humans and analysis of commercial soy isoflavone supplements. J Nutr 131:1362S-1375S, 2001.

35. Bloedon LT, Jeffcoat AR, Lopaczynski W, Schell MJ, Black TM, Dix KJ, Thomas BF, Albright C, Busby MG, Crowell JA, Zeisel SH. Safety and pharmacokinetics of purified soy isoflavones: single-dose administration to postmenopausal women. Am J Clin Nutr 76:11261137, 2002.

36. Mezei O, Banz WJ, Steger RW, Peluso MR, Winters TA, Shay N. Soy isoflavones exert antidiabetic and hypolipidemic effects through the PPAR pathways in obese Zucker rats and murine RAW 264.7 cells. J Nutr 133:1238-1243, 2003.

37. Khan E, bu-Amer Y. Activation of peroxisome proliferator-activated receptor-gamma inhibits differentiation of preosteoblasts. J Lab Clin Med 142:29-34, 2003.

38. Dang Z, Lowik CW. The balance between concurrent activation of ERs and PPARs determines daidzein-induced osteogenesis and adipogenesis. J Bone Miner Res 19:853-861, 2004.

39. Wang X, Kilgore MW. Signal cross-talk between estrogen receptor alpha and beta and the peroxisome proliferator-activated receptor gamma1 in MDA-MB-231 and MCF-7 breast cancer cells. Mol Cell Endocrinol 194:123-133, 2002.

40. Muthyala RS, Ju YH, Sheng S, Williams LD, Doerge DR, Katzenellenbogen BS, Helferich WG, Katzenellenbogen JA. Equol, a natural estrogenic metabolite from soy isoflavones: convenient preparation and resolution of R- and S-equols and their differing binding and biological activity through estrogen receptors alpha and beta. Bioorg Med Chem 12:1559-1567, 2004.

41. Hwang JT, Park IJ, Shin JI, Lee YK, Lee SK, Baik HW, Ha J, Park OJ. Genistein, EGCG, and capsaicin inhibit adipocyte differentiation process via activating AMP-activated protein kinase. Biochem Biophys Res Commun 338:694-699, 2005.

42. Szkudelska K, Nogowski L, Szkudelski T. Genistein affects lipogenesis and lipolysis in isolated rat adipocytes. J Steroid Biochem Mol Biol 75:265-271, 2000.

43. Bazuine M, van den Broek PJ, Maassen JA. Genistein directly inhibits GLUT4-mediated glucose uptake in 3T3-L1 adipocytes. Biochem Biophys Res Commun 326:511-514, 2005.

44. Kim HK, Nelson-Dooley C, la-Fera MA, Yang JY, Zhang W, Duan J, Hartzell DL, Hamrick MW, Baile CA. Genistein decreases food intake, body weight, and fat pad weight and causes adipose tissue apoptosis in ovariectomized female mice. J Nutr 136:409-414, 2006.

45. Chodon D, Ramamurty N, Sakthisekaran D. Preliminary studies on induction of apoptosis by genistein on HepG2 cell line. Toxicol In Vitro 21:887-891, 2007.

46. Po LS, Wang TT, Chen ZY, Leung LK. Genistein-induced apoptosis in MCF-7 cells involves changes in Bak and Bcl-x without evidence of anti-oestrogenic effects. Br J Nutr 88:463-469, 2002.

47. Kim S, Sohn I, Lee YS, Lee YS. Hepatic gene expression profiles are altered by genistein supplementation in mice with diet-induced obesity. J Nutr 135:33-41, 2005.

48. Lee YM, Choi JS, Kim MH, Jung MH, Lee YS, Song J. Effects of dietary genistein on hepatic lipid metabolism and mitochondrial function in mice fed high-fat diets. Nutrition 22:956-964, 2006.

49. Borradaile NM, de Dreu LE, Wilcox LJ, Edwards JY, Huff MW. Soya phytoestrogens, genistein and daidzein, decrease apolipoprotein B secretion from HepG2 cells through multiple mechanisms. Biochem J 366:531-539, 2002.

50. Owen AJ, Roach PD, Abbey M. Regulation of low-density lipoprotein receptor activity by estrogens and phytoestrogens in a HepG2 cell model. Ann Nutr Metab 48:269-275, 2004.

51. Mullen E, Brown RM, Osborne TF, Shay NF. Soy isoflavones affect sterol regulatory element binding proteins (SREBPs) and SREBPregulated genes in HepG2 cells. J Nutr 134:2942-2947, 2004.

52. Shin ES, Lee HH, Cho SY, Park HW, Lee SJ, Lee TR. Genistein downregulates SREBP-1 regulated gene expression by inhibiting site1 protease expression in HepG2 cells. J Nutr 137:1127-1131, 2007.

53. Wade GN, Gray JM, Bartness TJ. Gonadal influences on adiposity. Int J Obes 9(Suppl 1):83-92, 1985.

54. Lephart ED, Porter JP, Lund TD, Bu L, Setchell KD, Ramoz G, Crowley WR. Dietary isoflavones alter regulatory behaviors, metabolic hormones and neuroendocrine function in Long-Evans male rats. Nutr Metab (Lond) 1:16, 2004.

55. Penza M, Montani C, Romani A, Vignolini P, Pampaloni B, Tanini A, Brandi ML, onso-Magdalena P, Nadal A, Ottobrini L, Parolini O, Bignotti E, Calza S, Maggi A, Grigolato PG, Di LD. Genistein affects adipose tissue deposition in a dose-dependent and gender-specific manner. Endocrinology 147:5740-5751, 2006. 
56. Davis J, Higginbotham A, O’Connor T, Moustaid-Moussa N, Tebbe A, Kim YC, Cho KW, Shay N, Adler S, Peterson R, Banz W. Soy protein and isoflavones influence adiposity and development of metabolic syndrome in the obese male ZDF rat. Ann Nutr Metab 51: 42-52, 2007.

57. Ju YH, Allred CD, Allred KF, Karko KL, Doerge DR, Helferich WG. Physiological concentrations of dietary genistein dose-dependently stimulate growth of estrogen-dependent human breast cancer (MCF-7) tumors implanted in athymic nude mice. J Nutr 131:2957-2962, 2001.

58. Michael MR, Wolz E, Davidovich A, Pfannkuch F, Edwards JA, Bausch J. Acute, subchronic and chronic safety studies with genistein in rats. Food Chem Toxicol 44:56-80, 2006.

59. Song TT, Hendrich S, Murphy PA. Estrogenic activity of glycitein, a soy isoflavone. J Agric Food Chem 47:1607-1610, 1999.

60. Mezei O, Li Y, Mullen E, Ross-Viola JS, Shay NF. Dietary isoflavone supplementation modulates lipid metabolism via PPARalpha-dependent and -independent mechanisms. Physiol Genomics 26:8-14, 2006.

61. Ye JM, Doyle PJ, Iglesias MA, Watson DG, Cooney GJ, Kraegen EW. Peroxisome proliferator-activated receptor (PPAR)-alpha activation lowers muscle lipids and improves insulin sensitivity in high fatfed rats: comparison with PPAR-gamma activation. Diabetes 50:411417, 2001.

62. Evans RM, Barish GD, Wang YX. PPARs and the complex journey to obesity. Nat Med 10:355-361, 2004.

63. Manzoni MS, Rossi EA, Carlos IZ, Vendramini RC, Duarte AC, Damaso AR. Fermented soy product supplemented with isoflavones affected fat depots in juvenile rats. Nutrition 21:1018-1024, 2005.

64. Niesler CU, Siddle K, Prins JB. Human preadipocytes display a depotspecific susceptibility to apoptosis. Diabetes 47:1365-1368, 1998.

65. Gullicksen PS, Hausman DB, Dean RG, Hartzell DL, Baile CA. Adipose tissue cellularity and apoptosis after intracerebroventricular injections of leptin and 21 days of recovery in rats. Int J Obes Relat Metab Disord 27:302-312, 2003.

66. Peng Y, Kowalewski R, Kim S, Elkon KB. The role of IgM antibodies in the recognition and clearance of apoptotic cells. Mol Immunol 42: 781-787, 2005.

67. Slikker W Jr, Scallet AC, Doerge DR, Ferguson SA. Gender-based differences in rats after chronic dietary exposure to genistein. Int $\mathrm{J}$ Toxicol 20:175-179, 2001.

68. Penza M, Montani C, Romani A, Vignolini P, Pampaloni B, Tanini A, Brandi ML, onso-Magdalena P, Nadal A, Ottobrini L, Parolini O, Bignotti E, Calza S, Maggi A, Grigolato PG, Di LD. Genistein affects adipose tissue deposition in a dose-dependent and gender-specific manner. Endocrinology 147:5740-5751, 2006.

69. Kishida T, Mizushige T, Nagamoto M, Ohtsu Y, Izumi T, Obata A, Ebihara K. Lowering effect of an isoflavone-rich fermented soybean extract on the serum cholesterol concentrations in female rats, with or without ovariectomy, but not in male rats. Biosci Biotechnol Biochem 70:1547-1556, 2006.

70. Blair RM, Appt SE, netau-Pelissero C, Clarkson TB, Anthony MS, Lamothe V, Potter SM. Dietary soy and soy isoflavones have genderspecific effects on plasma lipids and isoflavones in golden Syrian $\mathrm{f}(1) \mathrm{b}$ hybrid hamsters. J Nutr 132:3585-3591, 2002.

71. Faughnan MS, Hawdon A, Ah-Singh E, Brown J, Millward DJ, Cassidy A. Urinary isoflavone kinetics: the effect of age, gender, food matrix and chemical composition. Br J Nutr 91:567-574, 2004.

72. Machinal F, Dieudonne MN, Leneveu MC, Pecquery R, Giudicelli Y. In vivo and in vitro ob gene expression and leptin secretion in rat adipocytes: evidence for a regional specific regulation by sex steroid hormones. Endocrinology 140:1567-1574, 1999.

73. Yang JY, Lee SJ, Park HW, Cha YS. Effect of genistein with carnitine administration on lipid parameters and obesity in C57B1/6J mice fed a high-fat diet. J Med Food 9:459-467, 2006.

74. Uesugi T, Fukui Y, Yamori Y. Beneficial effects of soybean isoflavone supplementation on bone metabolism and serum lipids in postmenopausal Japanese women: a four-week study. J Am Coll Nutr 21:97-102, 2002.

75. Kirk EA, Sutherland P, Wang SA, Chait A, LeBoeuf RC. Dietary isoflavones reduce plasma cholesterol and atherosclerosis in C57BL/6 mice but not LDL receptor-deficient mice. J Nutr 128:954-959, 1998.

76. Cheung C, Akiyama TE, Ward JM, Nicol CJ, Feigenbaum L, Vinson C, Gonzalez FJ. Diminished hepatocellular proliferation in mice humanized for the nuclear receptor peroxisome proliferator-activated receptor alpha. Cancer Res 64:3849-3854, 2004.

77. Wagner JD, Schwenke DC, Greaves KA, Zhang L, Anthony MS, Blair RM, Shadoan MK, Williams JK. Soy protein with isoflavones, but not an isoflavone-rich supplement, improves arterial low-density lipoprotein metabolism and atherogenesis. Arterioscler Thromb Vasc Biol 23:2241-2246, 2003.

78. Moriyama T, Kishimoto K, Nagai K, Urade R, Ogawa T, Utsumi S, Maruyama N, Maebuchi M. Soybean beta-conglycinin diet suppresses serum triglyceride levels in normal and genetically obese mice by induction of beta-oxidation, downregulation of fatty acid synthase, and inhibition of triglyceride absorption. Biosci Biotechnol Biochem 68:352-359, 2004.

79. Lovati MR, Manzoni C, Corsini A, Granata A, Fumagalli R, Sirtori CR. 7S globulin from soybean is metabolized in human cell cultures by a specific uptake and degradation system. J Nutr 126:2831-2842, 1996.

80. Peluso MR, Winters TA, Shanahan MF, Banz WJ. A cooperative interaction between soy protein and its isoflavone-enriched fraction lowers hepatic lipids in male obese Zucker rats and reduces blood platelet sensitivity in male Sprague-Dawley rats. J Nutr 130:23332342, 2000.

81. Chang HC, Churchwell MI, Delclos KB, Newbold RR, Doerge DR. Mass spectrometric determination of Genistein tissue distribution in diet-exposed Sprague-Dawley rats. J Nutr 130:1963-1970, 2000.

82. Yellayi S, Naaz A, Szewczykowski MA, Sato T, Woods JA, Chang J, Segre M, Allred CD, Helferich WG, Cooke PS. The phytoestrogen genistein induces thymic and immune changes: a human health concern? Proc Natl Acad Sci U S A 99:7616-7621, 2002.

83. Gu L, House SE, Prior RL, Fang N, Ronis MJ, Clarkson TB, Wilson ME, Badger TM. Metabolic phenotype of isoflavones differ among female rats, pigs, monkeys, and women. J Nutr 136:1215-1221, 2006.

84. Clifton-Bligh PB, Baber RJ, Fulcher GR, Nery ML, Moreton T. The effect of isoflavones extracted from red clover (Rimostil) on lipid and bone metabolism. Menopause 8:259-265, 2001.

85. Goodman-Gruen D, Kritz-Silverstein D. Usual dietary isoflavone intake is associated with cardiovascular disease risk factors in postmenopausal women. J Nutr 131:1202-1206, 2001.

86. Weickert MO, Reimann M, Otto B, Hall WL, Vafeiadou K, Hallund J, Ferrari M, Talbot D, Branca F, Bugel S, Williams CM, Zunft HJ, Koebnick C. Soy isoflavones increase preprandial peptide YY (PYY), but have no effect on ghrelin and body weight in healthy postmenopausal women. J Negat Results Biomed 5:11, 2006.

87. Hall WL, Vafeiadou K, Hallund J, Bugel S, Reimann M, Koebnick C, Zunft HJ, Ferrari M, Branca F, Dadd T, Talbot D, Powell J, Minihane AM, Cassidy A, Nilsson M, hlman-Wright K, Gustafsson JA, Williams CM. Soy-isoflavone-enriched foods and markers of lipid and glucose metabolism in postmenopausal women: interactions with genotype and equol production. Am J Clin Nutr 83:592-600, 2006.

88. Hsu CS, Shen WW, Hsueh YM, Yeh SL. Soy isoflavone supplementation in postmenopausal women. Effects on plasma lipids, antioxidant enzyme activities and bone density. J Reprod Med 46: 221-226, 2001.

89. Nikander E, Tiitinen A, Laitinen K, Tikkanen M, Ylikorkala O. Effects of isolated isoflavonoids on lipids, lipoproteins, insulin sensitivity, and ghrelin in postmenopausal women. J Clin Endocrinol Metab 89:3567-3572, 2004.

90. Vigna GB, Pansini F, Bonaccorsi G, Albertazzi P, Donega P, Zanotti 
L, De AD, Mollica G, Fellin R. Plasma lipoproteins in soy-treated postmenopausal women: a double-blind, placebo-controlled trial. Nutr Metab Cardiovasc Dis 10:315-322, 2000.

91. Scheiber MD, Liu JH, Subbiah MT, Rebar RW, Setchell KD. Dietary inclusion of whole soy foods results in significant reductions in clinical risk factors for osteoporosis and cardiovascular disease in normal postmenopausal women. Menopause 8:384-392, 2001.

92. Jenkins DJ, Kendall CW, Jackson CJ, Connelly PW, Parker T, Faulkner D, Vidgen E, Cunnane SC, Leiter LA, Josse RG. Effects of high- and low-isoflavone soyfoods on blood lipids, oxidized LDL, homocysteine, and blood pressure in hyperlipidemic men and women. Am J Clin Nutr 76:365-372, 2002.

93. McVeigh BL, Dillingham BL, Lampe JW, Duncan AM. Effect of soy protein varying in isoflavone content on serum lipids in healthy young men. Am J Clin Nutr 83:244-251, 2006.

94. Mackey R, Ekangaki A, Eden JA. The effects of soy protein in women and men with elevated plasma lipids. Biofactors 12:251-257, 2000.

95. Jenkins DJ, Kendall CW, Jackson CJ, Connelly PW, Parker T, Faulkner D, Vidgen E, Cunnane SC, Leiter LA, Josse RG. Effects of high- and low-isoflavone soyfoods on blood lipids, oxidized LDL, homocysteine, and blood pressure in hyperlipidemic men and women. Am J Clin Nutr 76:365-372, 2002.

96. McVeigh BL, Dillingham BL, Lampe JW, Duncan AM. Effect of soy protein varying in isoflavone content on serum lipids in healthy young men. Am J Clin Nutr 83:244-251, 2006.

97. Zhuo XG, Melby MK, Watanabe S. Soy isoflavone intake lowers serum LDL cholesterol: a meta-analysis of 8 randomized controlled trials in humans. J Nutr 134:2395-2400, 2004.

98. Taku K, Umegaki K, Sato Y, Taki Y, Endoh K, Watanabe S. Soy isoflavones lower serum total and LDL cholesterol in humans: a metaanalysis of 11 randomized controlled trials. Am J Clin Nutr 85:11481156, 2007.

99. Allen JK, Becker DM, Kwiterovich PO, Lindenstruth KA, Curtis C. Effect of soy protein-containing isoflavones on lipoproteins in postmenopausal women. Menopause 14:106-114, 2007.

100. Wu J, Oka J, Ezaki J, Ohtomo T, Ueno T, Uchiyama S, Toda T, Uehara M, Ishimi Y. Possible role of equol status in the effects of isoflavone on bone and fat mass in postmenopausal Japanese women: a double-blind, randomized, controlled trial. Menopause 14:866-874, 2007.

101. Frankenfeld CL, McTiernan A, Thomas WK, LaCroix K, McVarish L, Holt VL, Schwartz SM, Lampe JW. Postmenopausal bone mineral density in relation to soy isoflavone-metabolizing phenotypes. Maturitas 53:315-324, 2006.

102. Cassidy A, Brown JE, Hawdon A, Faughnan MS, King LJ, Millward J, Zimmer-Nechemias L, Wolfe B, Setchell KD. Factors affecting the bioavailability of soy isoflavones in humans after ingestion of physiologically relevant levels from different soy foods. J Nutr 136: 45-51, 2006.

103. Meyer BJ, Larkin TA, Owen AJ, Astheimer LB, Tapsell LC, Howe PR. Limited lipid-lowering effects of regular consumption of whole soybean foods. Ann Nutr Metab 48:67-78, 2004.

104. Song KB, Atkinson C, Frankenfeld CL, Jokela T, Wahala K, Thomas WK, Lampe JW. Prevalence of daidzein-metabolizing phenotypes differs between Caucasian and Korean American women and girls. J Nutr 136:1347-1351, 2006.

105. Ali AA, Velasquez MT, Hansen CT, Mohamed AI, Bhathena SJ. Modulation of carbohydrate metabolism and peptide hormones by soybean isoflavones and probiotics in obesity and diabetes. J Nutr Biochem 16:693-699, 2005.

106. McMullen MH, Hamilton-Reeves JM, Bonorden MJ, Wangen KE, Phipps WR, Feirtag JM, Kurzer MS. Consumption of Lactobacillus acidophilus and Bifidobacterium longum does not alter phytoestrogen metabolism and plasma hormones in men: a pilot study. J Altern Complement Med 12:887-894, 2006.
107. Nettleton JA, Greany KA, Thomas W, Wangen KE, Adlercreutz H, Kurzer MS. The effect of soy consumption on the urinary 2:16hydroxyestrone ratio in postmenopausal women depends on equol production status but is not influenced by probiotic consumption. $\mathrm{J}$ Nutr 135:603-608, 2005.

108. Kim E, Park H, Cha YS. Exercise training and supplementation with carnitine and antioxidants increases carnitine stores, triglyceride utilization, and endurance in exercising rats. J Nutr Sci Vitaminol (Tokyo) 50:335-343, 2004.

109. Feller AG, Rudman D. Role of carnitine in human nutrition. J Nutr 118:541-547, 1988.

110. Shin ES, Cho SY, Lee EH, Lee SJ, Chang IS, Lee TR. Positive regulation of hepatic carnitine palmitoyl transferase 1A (CPT1A) activities by soy isoflavones and L-carnitine. Eur J Nutr 45:159-164, 2006.

111. Wu J, Wang X, Chiba H, Higuchi M, Nakatani T, Ezaki O, Cui H, Yamada K, Ishimi Y. Combined intervention of soy isoflavone and moderate exercise prevents body fat elevation and bone loss in ovariectomized mice. Metabolism 53:942-948, 2004.

112. ubertin-Leheudre M, Lord C, Khalil A, Dionne IJ. Effect of 6 months of exercise and isoflavone supplementation on clinical cardiovascular risk factors in obese postmenopausal women: a randomized, doubleblind study. Menopause 14:624-629, 2007.

113. Jefferson WN, Padilla-Banks E, Newbold RR. Disruption of the female reproductive system by the phytoestrogen genistein. Reprod Toxicol 23:308-316, 2007.

114. Tousen Y, Umeki M, Nakashima Y, Ishimi Y, Ikegami S. Effects of genistein, an isoflavone, on pregnancy outcome and organ weights of pregnant and lactating rats and development of their suckling pups. $\mathrm{J}$ Nutr Sci Vitaminol (Tokyo) 52:174-182, 2006.

115. Lee BJ, Kang JK, Jung EY, Yun YW, Baek IJ, Yon JM, Lee YB, Sohn HS, Lee JY, Kim KS, Nam SY. Exposure to genistein does not adversely affect the reproductive system in adult male mice adapted to a soy-based commercial diet. J Vet Sci 5:227-234, 2004.

116. Jung EY, Lee BJ, Yun YW, Kang JK, Baek IJ, Jurg MY, Lee YB, Sohn HS, Lee JY, Kim KS, Yu WJ, Do JC, Kim YC, Nam SY. Effects of exposure to genistein and estradiol on reproductive development in immature male mice weaned from dams adapted to a soy-based commercial diet. J Vet Med Sci 66:1347-1354, 2004.

117. Waterland RA, Jirtle RL. Early nutrition, epigenetic changes at transposons and imprinted genes, and enhanced susceptibility to adult chronic diseases. Nutrition 20:63-68, 2004.

118. Fritz WA, Wang J, Eltoum IE, Lamartiniere CA. Dietary genistein down-regulates androgen and estrogen receptor expression in the rat prostate. Mol Cell Endocrinol 186:89-99, 2002.

119. Weaver IC, Cervoni N, Champagne FA, D'Alessio AC, Sharma S, Seckl JR, Dymov S, Szyf M, Meaney MJ. Epigenetic programming by maternal behavior. Nat Neurosci 7:847-854, 2004.

120. Setchell KD. Phytoestrogens: the biochemistry, physiology, and implications for human health of soy isoflavones. Am J Clin Nutr 68:1333S-1346S, 1998.

121. Klein SL, Wisniewski AB, Marson AL, Glass GE, Gearhart JP. Early exposure to genistein exerts long-lasting effects on the endocrine and immune systems in rats. Mol Med 8:742-749, 2002.

122. Strom BL, Schinnar R, Ziegler EE, Barnhart KT, Sammel MD, Macones GA, Stallings VA, Drulis JM, Nelson SE, Hanson SA. Exposure to soy-based formula in infancy and endocrinological and reproductive outcomes in young adulthood. JAMA 286:807-814, 2001.

123. Messina M, Caskill-Stevens W, Lampe JW. Addressing the soy and breast cancer relationship: review, commentary, and workshop proceedings. J Natl Cancer Inst 98:1275-1284, 2006. 